Eur. J. Clin. Chem. Clin. Biochem.

Vol. 32, 1994, pp. 495-500

(c) 1994 Walter de Gruyter \& Co. Berlin - New York

\title{
Tissue Kallikrein Activity and Kinin Release in Human Endothelial Cells
}

\author{
By K. Graf' ${ }^{1}$, M. Gräfe ${ }^{1}$, W. Auch-Schwelk' ${ }^{1}$, C. R. Baumgarten ${ }^{2}$, H. Scheffer ${ }^{2}$, A. Hildebrandt $^{3}$ and E. Fleck ${ }^{1}$ \\ ${ }^{1}$ Department of Internal Medicine and Cardiology, German Heart Institute, Berlin, Germany \\ ${ }^{2}$ Department of Clinical Immunology, Universitätsklinikuın Rudolf Virchow, Freie Universität Berlin, Bcrlin, \\ Germany \\ ${ }^{3}$ Bundesgesundheitsamt, Berlin, Germany
}

(Received January 18/April 13, 1994)

Summary: The kininogenase, tissue kallikrein (EC 3.4.21.8), has been identified in different blood vessels. The enzyme was mainly found in vascular smooth muscle cells. It is not known whether it is present and functionally active in vascular endothelial cells. The following study investigates the presence of tissue kallikrein in endothelial cells from human umbilical veins and pulmonary arteries. Tissue kallikrein was demonstrated in three ways:

1) by immunostaining in endothelial cells;

2) by measurement of tissue kallikrein activity using a colorimetric assay;

3) by the measurement of kinin release in intact and homogenised endothelial cells with a radioimmunoassay.

Immunostaining demonstrated the presence of tissue kallikrein in endothelial cells from human umbilical veins and endothelial cells from human pulmonary arteries. Tissue kallikrein-like activity, measured by the degradation of $D$ Val-cyclohexyl-Ala-Arg-4-nitraniline, was $3.57 \pm 0.5 \mathrm{mU} / 10^{6}$ endothelial cells from human umbilical veins and $7.52 \pm 0.84 \mathrm{mU} / 10^{6}$ endothelial cells from human pulmonary arteries. Intracellular kinin concentrations were $424 \pm 83 \mathrm{pg} / 10^{6}$ cells in endothelial cells from human umbilical veins and $576 \pm 146 \mathrm{pg} / 10^{6}$ cells in endothelial cells from human pulmonary arteries, and they increased in a time-dependent manner after homogenisation. The increase was abolished by aprotinin $(1000 \mathrm{kIU})$, an inhibitor of tissue kallikrein in both cell types. Addition of exogenous kallikrein ( $5 \mathrm{mU}$ ) to homogenised cells led to a five fold increase of kinin concentrations after five minutes, indicating a sufficient resource of cellular kininogen. Removal of extracellularly bound kininogen by washing with dextran sulphate $(100 \mathrm{mg} / \mathrm{l})$ resulted in an approximately $75 \%$ reduction of the cellular kinin release. This suggests that extracellular kininogen is the main source of endothelial kinin production. The present data demonstrate the presence of tissue kallikrein in human endothelial cells and provide evidence for the ability of human endothelial cells to release kinins.

\section{Introduction}

Kinins are potent vasodilators, which contribute to the local regulation of vascular tone $(1,2)$. Their vasorelaxant effect is mediated by the release of endotheliumderived relaxing factor and prostacyclin $(3,4)$. Kinins are released from kininogens by tissue (glandular) and plasma kallikreins, two serine proteases of restricted substrate specificity (5). Plasma kallikrein bound to high molecular weight kininogen circulates in the human blood. Presence of tissue kallikrein was shown in different tissues and body fluids, e.g. pancreas, submandibular glands and urine (5). Although the presence of tissue kallikrein in the endothelium has not been directly demonstrated, several pharmacological studies using the bradykinin-receptor antagonist, HOE 140, and angiotensin converting enzyme inhibitors suggest the presence of a kinin generating system in the endothelium (6-8).

In the vasculature, the occurrence of tissue kallikreinlike enzyme has been described in the adventitia of the 
rat (9) and in vascular smooth muscle cells isolated from the rat aorta (10). Saed (11) has demonstrated the presence of tissue kallikrein mRNA in rat arteries and veins and in isolated smooth muscle cells of the rat. Kallikrein-like activity is present in human tissue from aorta and renal arteries (12). Moshi and co-workers described a kininogenase in canine myocardium and aorta, which releases bradykinin and shows similarities with tissue kallikrein (13). However, most investigators attribute tissue kallikrein activity to the vascular smooth muscle cells, but not to endothelial cells, although the vascular endothelium seems to be one of the main targets of kinin action $(1-4)$. Therefore we investigated the presence of tissue kallikrein in cultured human endothelial cells by three different methods: immunostaining, measurement of enzyme activity, and measurement of kinin release.

\section{Materials and Methods}

Cell culture

Human umbilical vein endothelial cells were prepared according to the method of Jaffe (14) as previously described (15). For the preparation of human pulmonary artery endothelial cells, segments of human pulmonary arteries $\left(1.5-3.5 \mathrm{~cm}^{2}\right)$ were incubated in $2 \mathrm{~g} / 1$ collagenase (Roth, Karlsruhe, Germany) for 30 minutes at $37^{\circ} \mathrm{C}$. The segments were then rinsed with Medium 199 containing fetal calf serum, volume fraction 0.2 (Gibco-BRL, Berlin, Germany), and the detached cells were collected. The cell suspension was pelleted and seeded into a $35 \mathrm{~mm}$ dish (Falcon, Heidelberg, Germany) coated with $2 \mathrm{~g} / \mathrm{l}$ gelatine (Sigma, Deisenhofen, Germany) and incubated in culture medium at $37^{\circ} \mathrm{C}$ and $5 \% \mathrm{CO}_{2}$. The culture conditions for endothelial cells from human umbilical veins and endothelial cells from human pulmonary arteries were similar. The culture medium contained Medium 199, fetal calf serum (volume fraction 0.2$), 10^{5} \mathrm{U} / \mathrm{l}$ penicillin, $100 \mathrm{mg} / \mathrm{l}$ streptomycin, $10 \mathrm{mmol} / \mathrm{l}$ HEPES (all Sigma), $0.2 \mathrm{~mol} / 1 \mathrm{~L}$-glutamine (Seromed, Berlin, Germany), and $10 \mu \mathrm{g} / 1$ endothelial cell growth factor (Boehringer, Mannheim, Germany). All experiments were performed with cells of the second passage. The purity and identity of the endothelial cultures was determined by measuring factor VIII related antigen, using a specific antibody (Dako, Hamburg, Germany), and by measuring the uptake of fluorescence conjugated-low density lipoprotein in confluent monolayers (Paesel \& Lorei, Mainz, Germany) (16). Endothelial cells were counted using a haemocytometer.

Measurement of tissue kallikrein activity in endothelial cells

Confluent monolayers of endothelial cells from human umbilical veins and endothelial cells from human pulmonary arteries in 35 $\mathrm{mm}$ dishes were washed twice with phosphate-buffered saline (Gibco-BRL), scraped off the dish with a rubber policeman, suspended in $0.5 \mathrm{ml}$ Tris buffer $(0.1 \mathrm{~mol} / 1, \mathrm{pH} \mathrm{7.4})$, containing $1 \mathrm{ml} / 1$ Tween 20 (Serva, Heidelberg, Germany), then sonicated for 5 seconds (20\% output energy) with a Sonifier B-12 (Branson Sonic Power Co., Danbury, Co., USA) on ice. Samples of the cell homogenate were assayed immediately for tissue kallikrein activity.

\section{Kinin release in endothelial cell supernatants}

All experiments were done in $1.5 \mathrm{ml}$ serum-free incubation medium to avoid interference of the serum with the bradykinin RIA. The serum-free medium contained RPMI 1640 (Gibco-BRL), 10 $\mathrm{mmol} / \mathrm{l}$ HEPES (Sigma), antibiotics and the peptidase inhibitors, phosphoramidon (10 nmol/l) and lisinopril (1 $1 \mathrm{umol} / \mathrm{l}, \mathrm{ICl}, \mathrm{Ger}-$ many). Confluent monolayers were washed twice with phosphatebuffered saline, incubation medium was added, and the cells were incubated at $37^{\circ} \mathrm{C}$. After 10 minutes, 1 hour and 4 hours, aliquots of $0.2 \mathrm{ml}$ were taken, frozen in liquid nitrogen, and stored at $-70^{\circ} \mathrm{C}$ until measurement of kinin concentrations by RIA.

i

\section{Kinin release in endothelial cell homogenates}

All experiments were done in $2 \mathrm{ml}$ incubation medium. Confluent monolayers were washed twice with phosphate-buffered saline. Thereafter, the incubation medium was added and the cultures were allowed to equilibrate for 15 minutes. The cells were then scraped off the culture dish and homogenised by sonication as described above. Aliquots of $0.2 \mathrm{ml}$ were taken immediately after homogenisation and after 5 and 30 minutes. Aliquots were mixed with $0.2 \mathrm{ml}$ Tris-buffer $(0.2 \mathrm{~mol} / 1$ Tris, $0.01 \mathrm{~mol} / 1$ EDTA, pH 7.4, Serva AG, Heidelberg, Germany) on ice, frozen in liquid nitrogen, and stored at $=70^{\circ} \mathrm{C}$. Parallel experiments were performed in the presence of $1000 \mathrm{kIU} /$ dish aprotinin (Bayer AG, Leverkusen, Germany), which was added 15 minutes prior to homogenisation. In a second set of experiments, confluent cell monolayers were washed twice with dextran sulphate $(100 \mathrm{mg} / \mathrm{l}$, Sigma) for 4 minutes at room temperature. Then the cells were incubated with the incubation medium and bradykinin release was measured as described above. To some cell homogenates, 0.5 or $5 \mathrm{U} / 1$ porcine tissue kallikrein (Sigma) was added, and aliquots for kinin determination were taken at 5 , 30 and 60 minutes afterwards.

\section{Immunostaining}

Endothelial cells were placed in phosphate-buffered saline containing $10 \mathrm{~g} / \mathrm{l}$ bovine serum albumin (Sigma). Cytocentrifugal specimens containing $2 \times 10^{5}$ endothelial cells per slide were prepared using a Cytospin 2 (Shandon Southern Prod. Ltd., Runcorn, Cheshire, UK) at $150 \mathrm{~g}$ for 5 minutes. All cytocentrifuge slides were stained by the alkaline phosphatase anti-alkaline phosphatase method described by Cordell (17). The fixed cells were stained with an anti-human tissue kallikrein antiserum (dilution $1: 1000$ ) (18) or an antibody against factor VIII related antigen (dilution $1: 100$, Dako), which was used as positive control. Incubation with a preimmune antiserum (instead of kallikrein antibody) was performed as a negative control. After immunostaining, slides were counterstained with Mayer's acid haematoxylin. The number of positive cells was estimated by evaluation of 5 microscopic powerfields of each specimen (magnification $\times 200$; endothelial cells from human umbilical veins: $n=5$, endothelial cells from human pulmonary arteries: $n=3$ ).

\section{Assay for tissue kallikrein activity}

Tissue kallikrein activity was assessed by the colorimetric measurement of the release of 4-nitroaniline (19). Twenty microlitres of standard $(0.1,0.25,0.5,1,2,4,8 \mathrm{mU}$ porcine tissue kallikrein, Sigma) or sample were diluted in a total volume of $150 \mu$ $(0.1 \mathrm{~mol} / 1 \mathrm{Tris}, 0.234 \mathrm{~mol} / \mathrm{l} \mathrm{NaCl}, \mathrm{pH} 7.8)$. Assays were performed using 96-well titre plates (Falcon, Heidelberg, Germany). The enzymatic reaction was started by addition of $150 \mu \mathrm{l}$ of $0.5 \mathrm{mmol} / \mathrm{l}$ $D$-Val-cyclohexyl-Ala-Arg-4-nitraniline (Chromozym GK, Boehringer, Germany) in the presence and absence of $200 \mathrm{kIU}$ aprotinin (Bayer AG). The absorbance at $405 \mathrm{~nm}$ (Titertek MCC 340; Lausanne, Switzerland) was measured to determine the 4-nitroaniline release after 1,2, 3, and 6 hours. Tissue kallikrein activity was calculated from the maximal slope of 4-nitroaniline generation. One $\mathrm{mU}$ porcine tissue kallikrein (Sigma) induced an increase of $\Delta \mathrm{A}_{405 \mathrm{~nm}} / 10 \mathrm{~min}=0.052 \pm 0.005(\mathrm{n}=12)$. Only the activity of the reaction inhibited by aprotinin was attributed to tissue kallikrein-like activity. 


\section{Kinin radioimmunoassay}

Immunoreactive kinins were measured by a radioimmunoassay (RIA) described previously $(15,20)$. The detection limit of the RIA was $20 \mathrm{ng}$ per litre cell supernatant medium. The inter- and intraassay coefficients of variation were $4 \%$ and $5 \%$, respectively. The antiserum does not distinguish between lysyl-bradykinin (kallidin), bradykinin and methionyl-lysyl-bradykinin. The cross reactivity was less than $1 \%$ to des-9arg-bradykinin. The peptidase inhibitors added to the incubation medium did not interfere with the RIA at the concentrations used in the experiments. No cross reactivity of the bradykinin-antiserum to porcine tissue kallikrein was observed.

\section{Calculations and statistics}

Each experiment was done with duplicate or triplicate dishes. Results are shown as means \pm SEM ( $n=$ number of experiments). Cell numbers were separately counted in each experiment in one representative dish. Kinin concentrations measured in the homogenates were referred to $10^{6}$ endothelial cells. Statistical significance was analysed by the Mann-Whitney-U test for unpaired samples. P values less than 0.05 were accepted as statistically significant.

\section{Results}

\section{Immunostaining of tissue kallikrein}

The presence of tissue kallikrein immunoreactivity was demonstrated by immunostaining. The endothelial cells from umbilical veins labelled with the anti-human kallikrein antibody appeared red; between 55 and $78 \%$ of cells showed a positive staining $(n=5$, fig. 1$)$. The staining of endothelial cells from human pulmonary arteries demonstrated tissue kallikrein immunoreactivity in $65-75 \%$ of the cells $(n=3)$. Control staining with serum instead of the specific antibody resulted in no specific phosphatase reactions. Between 85 and $95 \%$ of cells $(n=3)$ gave a positive staining reaction with factor VIII related antigen.
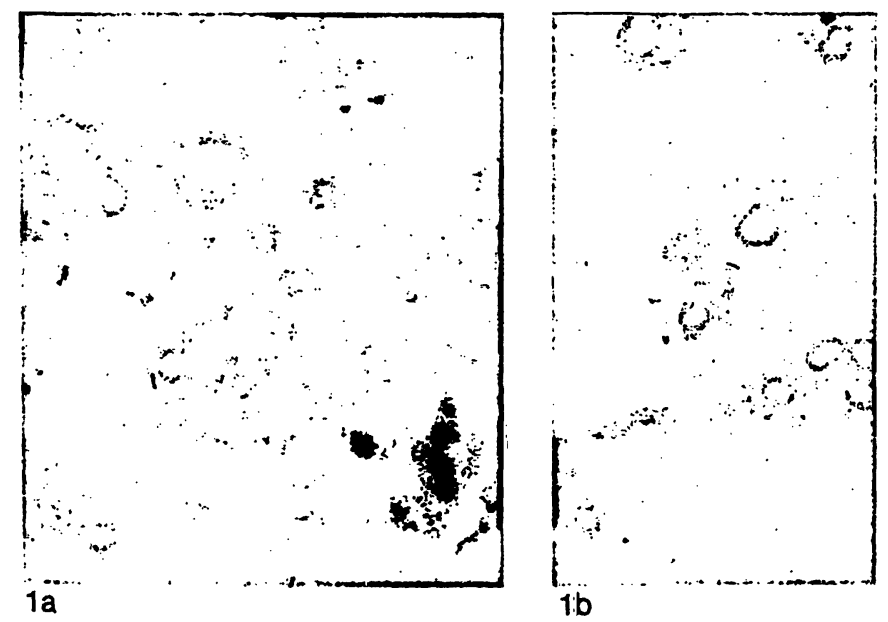

Fig. 1 Immunohistological detection of tissue kallikrein: a) light micrograph of endothelial cells from human umbilical veins stained with an anti-tissue kallikrein antibody;

b) control staining without first antibody (Haematoxylin stain, magnification $\times 110$ ).
2. Enzymatic activity of tissue kallikrein in endothelial cells

Kallikrein enzyme activity in cell homogenates of endothelial cells from human umbilical veins was detected by the cleavage of $D$-Val-cyclohexyl-Ala-Arg-4-nitraniline. The total activity was determined as $5.0 \pm 1.1 \mathrm{mU} / 10^{6}$ cells $(n=8)$, the activity inhibited by aprotinin, attributed to tissue kallikrein-like activity, was $3.57 \pm 0.47$ $\mathrm{mU} / 10^{6}$ cells in endothelial cells from human umbilical veins. In endothelial cells from human pulmonary arteries the total activity was $11.2 \pm 1.2 \mathrm{mU} / 10^{6}$ cells, and the tissue kallikrein-like activity was $7.52 \pm 0.82 \mathrm{mU} /$ $10^{6}$ cells $(n=4, p<0.01$ vs. endothelial cells from human umbilical veins).

\section{Kinin release into supernatants}

In the presence of the angiotensin converting enzymeinhibitor, lisinopril, and the neutral endopeptidase 24.11inhibitor, phosphoramidon, the following kinin-concentrations were measured: 10 minutes $40 \pm 18 \mathrm{ng} / \mathrm{l}, 1$ hour $52 \pm 23 \mathrm{ng} / \mathrm{l}, 4$ hours $35 \pm 15 \mathrm{ng} / \mathrm{l}(\mathrm{n}=9$ at each time point). No immunoreactive kinins were detected in the incubation medium alone, or in supernatants without the peptidase inhibitors, at all time points $(n=6)$.

\section{Kinin release in endothelial cells from human umbilical veins}

No immunoreactive kinins were detected after homogenisation of cells in the absence of the peptidase inhibitors, lisinopril and phosphoramidon. In the presence of both inhibitors, kinin contents of $424 \pm 83 \mathrm{pg} / 10^{6}$ cells $(\mathrm{n}=8)$ were measured directly after homogenisation. After 5 minutes, the kinin concentration increased further to $627 \pm 57 \mathrm{pg} / 10^{6}$ cells $(\mathrm{n}=8)$ and remained nearly unchanged during 30 minutes. The presence of the tissue kallikrein inhibitor, aprotinin (1000 kIU/dish), resulted in significantly lower concentrations at all time points $(P<0.05$ vs. control). Treatment of the cells with $100 \mathrm{mg} / \mathrm{l}$ dextran sulphate reduced the cellular kinin content from $424 \pm 83 \mathrm{pg} / 10^{6}$ cells to $102 \pm 14 \mathrm{pg} / 10^{6}$ cells $(n=8, p<0.01)$. After 5 and 30 minutes, the kinin concentrations increased further to $150 \pm 23 \mathrm{pg} / 10^{6}$ cells $(n=8)$ and $186 \pm 31 \mathrm{pg} / 10^{6}$ cells $(n=8$, $\mathrm{p}<0.05$ to 0 minutes; fig. 2a).

Addition of $5 \mathrm{mU}$ tissue kallikrein immediately after homogenisation resulted in a fivefold increase during the first 5 minutes up to $2575 \pm 400 \mathrm{pg} / 10^{6}$ cells $(\mathrm{n}=6$, $\mathrm{p}<0.01$ ), which declined during the following $25 \mathrm{mi}$ nutes (fig. 3). 

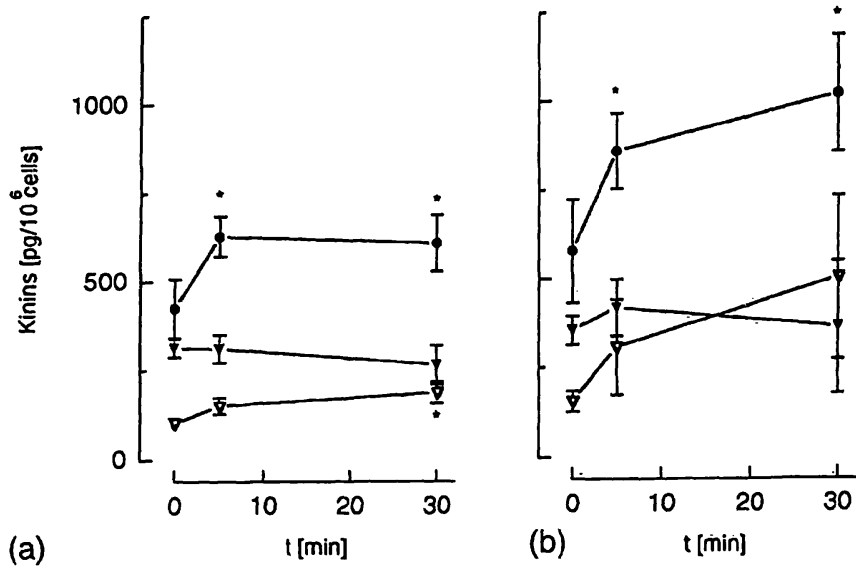

Fig. 2 Cellular kinin concentrations immediately after homogenisation and 5 and 30 minutes later in

a) endothelial cells from human umbilical veins, and in

b) endothelial cells from human pulmonary arteries.

Controls (filled circles), endothelial cells treated with dextran sulphate $(100 \mathrm{mg} / \mathrm{l})$ before homogenisation (open triangles), and cells incubated with aprotinin $(1000 \mathrm{kIU} / \mathrm{dish}$, filled triangles * $\mathrm{P}<0.05$ vs. 0 minute).

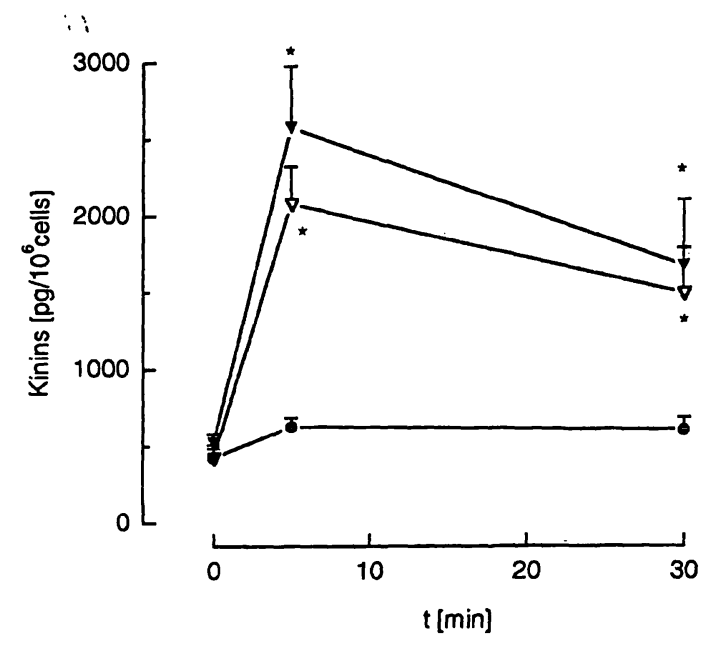

Fig. 3 Cellular kinin concentrations in endothelial cells from human umbilical veins immediately after homogenisation and 5 and 30 minutes after addition of $0.5 \mathrm{mU}$ porcine kallikrein (open triangles) and $5 \mathrm{mU}$ tissue kallikrein (filled triangles), compared with controls without kallikrein addition (filled circles) $(n=9$ each $* \mathrm{P}<0.05$ vs. control).

\section{Kinin release in endothelial cells from human pulmonary arteries}

Similar experiments were performed with endothelial cells derived from the human pulmonary artery. In homogenates of endothelial cells from human pulmonary arteries, no immunoreactive kinins were detected without the peptidase inhibitors. In the presence of lisinopril and phosphoramidon, kinin contents of $576 \pm 146$ $\mathrm{pg} / 10^{6}$ cells $(\mathrm{n}=4)$ were detected immediately after homogenisation. After 5 and 30 minutes, the kinin concentration significantly increased to $857 \pm 106 \mathrm{pg} / 10^{6}$ cells and $1117 \pm 165 \mathrm{pg} / 10^{6}$ cells $(n=4$, fig. 2 , left panel), and was unchanged after 60 mintes $(960 \pm 60$ $\mathrm{pg} / 10^{6}$ cells, $\mathrm{n}=4$, not shown in fig. 2). As in endo- thelial cells from human umbilical veins, the release of kinins was reduced in the presence of aprotinin. The kinin concentrations remained unchanged 30 minutes after homogenisation. Treatment of the cells with dextran sulphate significantly decreased cellular kinin concentrations (155 $\pm 28 \mathrm{pg} / 10^{6}$ c cells, $\mathrm{n}=4, \mathrm{p}<0.05$ ). The kinin concentrations increased after 5 minutes to $305 \pm 124 \mathrm{pg} / 10^{6}$ cells and after 30 minutes to 500 $\pm 245 \mathrm{pg} / 10^{6}$ cells $(\mathrm{n}=4$, fig. $2 \mathrm{~b}$ ).

\section{Discussion}

The present data provide immunohistological and functional evidence for the presence of tissue kallikrein in cultured endothelial cells from human umbilical veins and pulmonary arteries. About two thirds of the endothelial cells from umbilical veins and pulmonary arteries showed positive staining after immunostaining with a highly specific antiserum against tissue kallikrein (18). The control staining with the endothelial marker (factor VIII related antigen) was positive in nearly all the cells. This confirmed that the tissue kallikrein-immunoreactivity can be attributed to human endothelial cells. The tissue kallikrein antigen was not found in all the cells, possibly because low quantities of kallikrein are present, or the staining technique has low sensitivity. We observed a similar pattern of positive and negative cells in human smooth muscle cells (21). As reported previously by various authors $(9-13)$, tissue kallikrein is present in vascular smooth muscle cells. Therefore, the apparent absence of immunoreactivity in some endothelial cells may be due to a methodological problem. In all experiments the majority of the endothelial cells were positive for tissue-kallikrein immunoreactivity.

Tissue kallikrein-like activity was measured by a well characterised colorimetric assay (19). Since the specificity of chromogenic substrates is not very high, we performed parallel measurements in the presence of the tissue kallikrein inhibitor, aprotinin, to exclude major unspecific protease activity, including plasma kallikrein. Aprotinin blocked more than $75 \%$ of the total enzymatic activity in endothelial cells. These results might indicate that the major kininogenase activity in endothelial cell can be attributed to a tissue kallikrein-like enzyme.

Kinins are generated by enzymatic cleavage of high molecular weight kininogen and low molecular weight kininogen by kallikreins. Both kininogens are synthesised in the liver and are found in plasma. High molecular mass kininogen binding sites have been detected on cultured endothelial cells $(22,23)$. A recently pub- lished study shows binding of high molecular mass kininogen to the endothelium of human umbilical veins in situ and the generation of bradykinin from the receptor- 
bound high molecular weight kininogen after addition of plasma kallikrein (24). Therefore, it seems likely that high molecular weight kininogen is the major substrate of the endothelial kinin generation. Van Iwaarden et al. (22) reported that treatment of endothelial cells with dextran sulphate completely removed the receptorbound high molecular weight kininogen. In our experiments, an approximately $75 \%$ reduction of kinin release in endothelial cells from human umbilical veins and endothelial cells from human pulmonary arteries occurred after washing with dextran sulphate. This indicates that the main source of kininogen is receptor-bound extracellular kininogen. Only the minor part of kininogen appears to be localized intracellularly. Whether intracellular kininogen is synthesised by endothelial cells or derives from serum or plasma is controversely discussed in various reports $(22-24)$. In our study the intracellular kinin concentrations measured immediately after homogenisation were within the range of concentrations causing physiological responses like vasodilatation (1, $2,6)$ and were 8 to 10 fold higher than the kinin concentrations found in the supernatants. We measured a further increase of kinin generation in endothelial cells during the following 30 minutes after homogenisation. The increase of kinin generation during this time can be explained by further cleavage of kininogen by cellular proteases, including kallikreins. Parallel incubation with the protease inhibitor, aprotinin, an inhibitor of tissue kallikrein, reduced cellular kinin concentrations and abolished the increase of kinins in the homogenates during this time period, suggesting a role for tissue kallikrein in endothelial kinin formation.

Since human umbilical vein endothelial cells are often considered to be embryonic cells, which might be different from adult phenotypes, we performed parallel experiments with adult endothelial cells derived from segments of the pulmonary artery. We obtained similar results for the measurement of tissue kallikrein-like activity and cellular kinin formation in endothelial cells from the pulmonary circulation, which confirms the results of the experiments with endothelial cells from human umbilical veins. Different amounts of kallikreinlike activity were measured in endothelial cells from hu-

\section{References}

1. Roman, R. J., Kaldunski, M. L., Scicli, A. G. \& Carretero, O. A. (1988) Influence of kinins and angiotensin II on the regulation of papillary blood flow. Am. J. Physiol. 255, F690F698.

2. Auch-Schwelk, W., Kuchenbuch, C., Claus, C., Walther, B., Bossaller, C., Friedel, N., Graf, K., Gräfe, M. \& Fleck, E. (1993) Local regulation of vascular tone by bradykinin and angiotensin converting enzyme inhibitors. Eur. Heart. J. 14 (suppl. I), 154-160. man umbilical veins and endothelial cells from human pulmonary arteries. It has been reported before that tissue-like kallikrein activity varies in homogenates from different human vessels (12).

The present data demonstrate that certain requirements have to be met to measure kinin formation and release from endothelial cells. The most important condition is the inhibition of bradykinin degrading enzymes. The most potent of these is angiotensin converting enzyme (2). Another kininase II, the neutral endopeptidase 24.11 , is also involved in the degradation of bradykinin (25). Intra- and extracellular kinins were only detected when both enzymes had been blocked by inhibitors. The second requirement is the exogenous supply of kininogen $(22,24)$, which is normally present in cell culture medium. Whether disintegration (like homogenisation) of the cells is a requirement for kinin release is not sure. However, we measured much higher concentrations of kinins in homogenates than in supernatants. Present data from different studies $(6,8,25)$ indicate that physiological stimuli like flow, shear stress or ischaemia might be a stimulus for local kinin release.

A recent publication by Wang and colleagues provides evidence that tissue kallikrein is a powerfull modulator of blood pressure in vivo (26). Transgenic mice carrying the human tissue kallikrein gene demonstrated hypotensive blood pressure, when tissue kallikrein was overexpressed in tissues and serum. Recent cloning of human tissue kallikrein gene and its transcripts from colon (27) might provide the basis for detailed investigation of tissue kallikrein expression in endothelial cells in the near future.

In the present study we demonstrated that tissue kallikrein is present in human endothelial cells derived from umbilical veins and pulmonary arteries, and that it contributes to local kinin formation in vitro.

\section{Acknowledgement}

The authors thank Mrs $U$. Meisel-Rott and Mrs $K$. Vetter for excellent technical assistance. The results were presented in part at the scientific sessions of the American Heart Association 1991.
3. Cherry, P. D., Furchgott, R. F., Zawadski, T. V. \& Jothianandan, D. (1982) Role of endothelial cells in relaxation of isolated arteries by bradykinin. Proc. Natl. Acad. Sci. USA 79, $105-110$.

4. McIntyre, T. M., Zimmerman, G. A., Satoh, K. \& Prescott, S. M. (1985) Cultured endothelial cells synthesise both platelet activating factor and prostacyclin in response to histamine, bradykinin, and adenosine triphosphate. J. Clin. Invest. 76, $271-280$. 
5. Frey, E. K., Kraut, H. \& Werle, E. (1977) Kallikicin Padutin. Stuttgart, Germany, Ferdinand Enke Verlag.

6. Wiemer, G., Schölkens, B. A., Becker, R. H. A. \& Busse, R. (1991) Ramiprilat enhances endothelial autacoid formation by inhibiting breakdown of endothelium-derived bradykinin. Hypertension 18. 558-563.

7. Busse, R. \& Lamontagne, D. (1991) Endothelium-derived bradykinins is responsible for the increase in calcium produced by angiotensin-converting enzyme inhibitors in human endothelial cells. Naunyn. Schmiedebergs Arch. Pharmacol. 344, 126-129.

8. Baumgarten, C. R., Linz, W., Kunkel, G., Schölkens, B. A. \& Wiemer, G. (1993) Ramiprilat increases bradykinin outflow from isolated rat hearts. Br. J. Pharmacol. 108, 293-295.

9. Oza, N. B., Schwartz, J. H., Goud, H. D. \& Levinsky, N. G. (1990) Rat aortic smooth muscle cells in culture express kallikrein, kininogen, and bradykinase activity. J. Clin. Invest. 85, 597-600.

10. Nolly, H., Scicli, A. G., Scicli, G. \& Carretero, O. A. (1985) Characterisation of a kininogenase from rat vascular tissue resembling glandular kallikrein. Circ. Res. 56, 816-821.

11. Saed, G. M., Carreteto, O. A., MacDonald, R. J. \& Scicli, A. G. (1990) Kallikrein messenger RNA in rat arteries and veins. Circ. Res. 67, 510-516.

12. Madeddu, P., Gherli, T., Bacciu, P. B., Maioli, M. \& Glorioso, N. (1993) A kallikrein-like enzyme in human vascular tissue. Am. J. Hypertens. 6, 344-348.

13. Moshi, M. J., Zeitlin, I. J., Wainwright, C. L. \& Parrat, J. R. (1992) Acid optimum kininogenases in canine myocardium and aorta. Cardiovasc. Res. 26, 367-370.

14. Jaffe, E. A., Nachman, R. L., Becker, C. G. \& Minick, C. R. (1973) Culture of human endothelial cells derived from umbilical veins. Identification by morphologic and immunologic criteria. J. Clin. Invest. 52, 2745-2756.

15. Gräfe, M., Bossaller, C., Graf, K., Auch-Schwelk, W., Baumgarten, C. R., Hildebrand, A. \& Fleck, E. (1993) Effect of angiotensin converting enzyme inhibition on bradykinin metabolism by human vascular endothelial cells. Am. J. Physiol. 264, H1493-H1497.

16. Voyta, J. C., Via, D. P., Butterfield, C. E. \& Zetter, B. R. (1984) Identification and isolation of endothelial cells based on their increased uptake of acetylated-low density lipoprotein. J. Cell. Biol. 99, 2034-2040.

17. Cordell, J., Falini, B., Eivier, O. N., Gosh, A. K., Abdulaziz, Z., MacDonald, S., Polford, K., Stein, H. \& Mason, D. Y. (1984) Immunoenzymatic labelling of monoclonal antibodies using immune complexes of alkaline phosphatase and monoclonal anti-alkaline phosphatase (APAAP complexes). J. Histochem. Cytochem. 32, 219-227.

18. Baumgarten, C. R., Schwarting, R. \& Kunkel, G. (1989) Localisation of glandular kallikrein in nasal mucosa of allergic and non allergic individuals. Adv. Exp. Med. Biol. 247B, 523-528.

19. Amundsen, E., Potter, J., Friberger, P., Knos, M., Larsbraten, M. \& Claeson, G. (1979) Methods for determination of glandular kallikrein by means of a chromogenic tripeptide substrate. Adv. Exp. Med. Biol. 120a, 83-95.

20. Proud, D., Togias, A., Naclerio, R. M., Crush, S. A., Norman, P. S. \& Liechtenstein, L. M. (1983) Kinins are generated in vivo following nassal airway challenge of allergic individuals with allergen. J. Clin. Invest. 72, 1678-1685.

21. Graf, K., Gräfe, M., Bossaller, C., Baumgarten, C. R., AuchSchwelk, W. \& Fleck, E. (1991) Kininogenase augments bradykinin concentrations in endothelial and smooth muscle cells in culture. Circulation 84 (suppl.), 624.

22. Van Iwaarden, F., de Groot, P. G., Sixma, J. J. \& Bouma, B. N. (1988) High-molecular weight kininogen is present in cultured human endothelial cells: Localisation, isolation and characterisation. Blood $71,1268-1276$.

23. Schmaier, A. H., Kuo, A., Lundberg, D., Murray, S. \& Cines, D. (1988) The expression of high molecular weight kininogen on human umbilical vein endothelial cells. J. Biol. Chem. 263, $16327-16333$.

24. Graf, K., Gräfe, M., Bossaller, C., Niehụs, J., Schulz, K. D., Auch-Schwelk, W. \& Fleck, E. (1993) Degradation of bradykinin by neutral endopeptidase 24.11 in cultured human endothelial cells. Eur. J. Clin. Chem. Clin. Biochem. 31, 267-272.

25. Nishikawa, K., Shibayama, Y., Kuna, P., Calcaterra, E., Kaplan, A. P. \& Reddigari, S. R. (1992) Generation of vasoactive peptide bradykinin from human umbilical vein endothelium bound high molecular weight kininogen by plasma kallikrein. Blood 80, 1980-1988.

26. Wang, J., Xiong, W., Yang, Z., Davis, T., Dewey, M. J., Chao, J. \& Chao, L. (1994) Human tissue kallikrein induces hypotension in transgenic mice. Hypertension 23, 236-243.

27. Chen, L.-M., Murray, S. R., Chai, K. X., Richards, G. P., Chao, J. \& Chao, L. (1993) Molecular cloning and characterization of human tissue kallikrein and a novel kallikrein transcripts in colon. Kinin 93; p. 17.

Dr. med. Kristof Graf

German Heart Institute Berlin

Department of Internal Medicine and Cardiology Augustenburger Platz 1

D-13353 Berlin

Germany 